\title{
PENGARUH SUHU DAN LAMA FERMENTASI TERHADAP UJI ORGANOLEPTIK PADA PEMBUATAN NATA BUAH ENAU (Areng pinnata Merr)
}

\author{
Marselia Latumahina ${ }^{1}$, Ali Awan², D. Rumahlatu ${ }^{2}$ \\ ${ }^{1}$ Alumni Program Studi Pendidikan Biologi \\ ${ }^{2}$ Dosen Program Studi Pendidikan Biologi
}

E-mail: aliawanprof@gmail.com

\begin{abstract}
Background: Enau is one of the natural resources in the tropics, its distribution is widespread, very necessary and easy to obtain for daily use by local people as a sustainable natural resource. Palm fruit in terms of chemical composition has a low nutritional value, but "kolang-kaling" fiber is very good for health, to reduce fruit damage, then palm fruit is processed into nata which has a high economic value.

Method: Making nata de arenga pinnata Merr is aided by microorganisms, namely the bacterium Aceetobacter xylinum. The type of research used is the type of experimental research that is to see the difference in the organoleptic test scores of palm fruit (Arenga pinnata Merr). This research was conducted on December 5 to December 20, 2016.

Results: The results showed that organoleptic tests had white, tasteless, chewy texture and a nonsour aroma.

Conclusion: There is an influence of temperature with fermentation time on organoleptic test values on the manufacture of palm fruit nata, namely the color and texture of palm fruit nata. Whereas in taste and aroma there is no influence of temperature and duration of fermentation on organoleptic test values on the making of palm fruit nata.
\end{abstract}

Keywords: Nata de Arenga pinnata, temperature, duration of fermentation, organoleptic value

\begin{abstract}
Abstrak
Latar Belakang: Enau merupakan salah satu sumber daya alam di daerah tropis, distribusinya tersebar luas, sangat diperlukan dan mudah didapatkan untuk keperluan sehari-hari oleh masyarakat setempat sebagai sumber daya alam yang berkesinambungan. Buah enau dari segi komposisi kimia memiliki nilai gizi yang rendah, akan tetapi serat "kolang-kaling" baik sekali untuk kesehatan, untuk mengurangi kerusakaan buah, maka buah enau diolah menjadi nata yang memiliki nilai ekonomis yang tinggi.

Metode: Pembuatan nata de arenga pinnata Merr di bantu oleh mikroorganisme yakni bakteri Aceetobacter xylinum. Jenis penelitian yang digunakan adalah jenis penelitian eksperimen yaitu untuk melihat perbedaan terhadap nilai uji organoleptik nata buah enau (Arenga pinnata Merr). Penelitian ini dilaksanakan pada tanggal 05 Desember sampai 20 Desember 2016.

Hasil: Hasil menunjukkan pada pengujian organoleptik memiliki warna putih, rasa tawar, tekstur kenyal dan aroma tidak beraroma asam.

Kesimpulan: Adanya pengaruh suhu dengan lama fermentasi terhadap nilai uji organoleptik pada pembuatan nata buah enau yaitu pada warna dan tekstur nata buah enau. Sedangkan pada rasa dan aroma tidak terdapat pengaruh suhu dan lama fermentasi terhadap nilai uji organoleptik pada pembuatan nata buah enau.
\end{abstract}

Kata Kunci: nata de Arenga pinnata, suhu, lama fermentasi, nilai organoleptik. 


\section{PENDAHULUAN}

Aren atau enau (Arenga pinnata Merr) merupakan salah satu sumber daya alam di daerah tropis, distribusinya tersebar luas, sangat diperlukan dan mudah didapatkan untuk keperluan sehari-hari oleh masyarakat setempat sebagai sumber dayaa alam yang berkesinambungan. Hampir semua bagian atau produk tanaman ini dapat dimanfaatkan dan memiliki nilai ekonomi. Semua bagian pohon aren dapat diambil manfaatnya, mulai dari bagian-bagian fisik pohon maupun dari hasil-hasil produksinya, misalnya: akar (untuk obat tradisional dan peralatan), batang (untuk berbagai macam peralatan dan bangunan), daun muda atau janur (untuk pembungkus atau pengganti kertas rokok yang disebut dengan kawung) buah muda (dapat dijadikan kolang-kaling) (Sumarni, $d k k, 2003$ ).

Temperatur ruang inkubasi harus diperhatikan karena berkaitan dengan pertumbuhan bakteri Acetobakter xylinum dapat tumbuh dan berkembang secara optimal. Pada umumnya suhu fermentasi untuk pembuatan nata adalah pada suhu kamar $\left(28^{\circ} \mathrm{C}\right)$. Suhu yang terlalu rendah atau terlalu tinggi akan mengganggu pertumbuhan bakteri pembentuk nata, yang akhirnya juga menghambat produksi nata (Pramesti, 2007). Sedangkan menurut Pambayun (2002), suhu yang dibutuhkan dalam pembuatan nata adalah suhu kamar $\left(28^{\circ} \mathrm{C}-31^{\circ} \mathrm{C}\right)$. Suhu yang terlalu tinggi ataupun rendah akan menghasilkan nata yang kurang berkualitaas atau aktifitas Acetobakter xylinum terhambat. Suhu yang memungkinkan untuk pembentukan nata adalah pada suhu kamar, dengan bantuan bakteri Acetobacter xylinum maka komponen gula yang terdapat di dalamnya dapat dirubah menjadi suatu substansi yang menyerupai gel yang tumbuh di permukaan media (Nadiyah, 2005).

Fermentasi merupakan pengolahan substrat menggunakan peranan mikroba (jasad renik) sehingga dihasilkan produk yang dikehendaki (Muhidin, 2001). Bakteri Acetobacter xylinum akan beradaptasi dengan lingkungan (media) selama 3 hari. Tanda awal tumbuhnya bakteri Acetobacter xylinum dapat dilihat dari keruhnya media cair tadi setelah difermentasi selama 24 jam pada suhu kamar. Lapisan tipis yang tembus cahaya mulai terbentuk dipermukaan media dan cairan di bawahnya menjadi semakin jernih setelah difermentasi selama 36-48 jam (Saragih, 2004).

Nata merupakan produk makanan fermentasi yang tersusun atas selulosa ekstraselular yang di produksi oleh bakteri Acetobacter xylinum dengan memanfaatkan gula dalam media fermentasi (Sumiyatni, 2009). Pembentukan nata memerlukan starter sebanyak $10-20 \%$ dari volume media sebagai starter mikroba. Adanya jumlah stater yang sesuai, maka bakteri dapat mencapai pertumbuhan secara optimum. Umur kultur Acetobacter xylinum yang digunakan dalam fermentasi berpengaruh terhadap pembentukan nata (Saragih, 2004).

Organoleptik merupakan pengujian secara subjektif yaitu suatu pengujian penerimaan selera makanan (acceptance) yang didasarkan atas pengujian kegemaran (preference) dan analisa pembeda (difference analysis). Mutu organoleptik didasarkan pada kegiatan penguji (panelis) yang pekerjaannya mengamati dan menilai secara organoleptik (Winarno, 2004).

\section{MATERI DAN METODE}

Jenis penelitian yang digunakan adalah jenis penelitian eksperimen yaitu untuk melihat perbedaan terhadap nilai uji organoleptik nata buah enau (Arenga pinnata Merr). Lokasi pengambilan sampel Desa Waiyari Kecamatan Salahutu Kota Ambon. Penelitian ini dilaksanakan di Laboratorium Jurusan Biologi Fakultas MIPA Universitas Pattimura Ambon. Penelitian ini dilaksanakan pada tanggal 05 Desember sampai 20 Desember 2016.

Pelaksanaan pembuatan nata de pinnata dengan tahapan sebagai berikut menurut (Susanti, 2006). Menyiapkan alat dan bahan yang diperlukan berupa sterilisasi alat dan menimbang bahanbahan yang diperlukan.

\section{Tahap Pengambilan Sari Buah Enau}

Buah enau dikupas dengan pisau, dicuci dengan air hingga bersih, kemudian dipotong-potong dengan pisau kemudian diblender dengan menambahkan air 
sebanyak $400 \mathrm{ml}$, kemudian disaring dan diambil sarinya.

\section{Tahap Pembuatan Media}

Sari buah enau sebanyak $2000 \mathrm{ml}$ dididihkan dengan menggunakan kompor, menjelang mendidih tambahkan ekstrak tauge $1000 \mathrm{ml}$ dan gula pasir $100 \mathrm{~g}$, biarkan mendidih kurang lebih 10 menit dengan membuang buih yang mengapung di atas dengan menggunakan saringan. Setelah itu media sari buah enau diangkat, diberi asam cuka sebanyak $20 \mathrm{ml}$, diaduk dengan sendok hingga tercampur rata. Kemudian dimasukkan ke dalam toples loyang plastik yang sudah disterilkan. Media dalam toples kemudian ditutup dengan koran yang sudah diuapkan dan biarkan selama 12 jam.

\section{Tahap fermentasi}

Starter dimasukkan kemudian campurkan hingga rata. Media toples kemudian ditutup dengan koran kembali dan diikat dengan karet. Setelah itu media nata kemudian diletakkan pada ruangan fermentasi dengan suhu kamar $28^{\circ} \mathrm{C}$ dan suhu rendah $31^{\circ} \mathrm{C}$ dengan waktu pengamatan, 10 hari, dan 14 hari.

\section{Tahap pemanenan}

Setelah hari yang ditentukan tutup toples dibuka, nata kemudian diambil dan dicuci dengan air yang mengalir sampai bersih. Kemudian nata tersebut kemudian dipotong dengan pisau, direbus dengan air untuk menghilangkan sisa asam selama 15 menit dan diuji organoleptiknya oleh 10 orang panelis.

Teknik pengumpulan data dalam penelitian ini adalah uji Organoleptik menggunakan kuesioner untuk menilai seberapa besar minat konsumen terhadap produk yang dihasilkan. Panelis akan memberi penilaian khusus terhadap tekstur, rasa, warna dan aroma dengan menggunakan pengujian secara uji hedonik.
Warna

Tabel 1. Penilaian Terhadap Warna Nata de Pinnata.

\begin{tabular}{cl}
\hline Skala numerik & \multicolumn{1}{c}{ Warna } \\
\hline 4 & Sangat putih \\
3 & Putih \\
2 & Agak putih \\
1 & Putih kecoklatan \\
\hline
\end{tabular}

Rasa

Tabel 2. Penilaian Terhadap Rasa Nata de Pinnata.

\begin{tabular}{cl}
\hline Skala numerik & \multicolumn{1}{c}{ Rasa } \\
\hline 4 & Sangat tawar \\
2 & Tawar \\
2 & Agak tawar \\
1 & Tidak tawar \\
\hline
\end{tabular}

Tekstur

Tabel 3. Penilaian Terhadap Tekstur Nata de Pinnata

\begin{tabular}{cl}
\hline Skala numerik & \multicolumn{1}{c}{ Tekstur } \\
\hline 4 & Sangat kenyal \\
3 & Kenyal \\
2 & Agak kenyal \\
1 & Tidak kenyal \\
\hline
\end{tabular}

Aroma

Tabel 4. Penilaian Terhadap Aroma Nata de Pinnata

\begin{tabular}{cl}
\hline Skala numerik & \multicolumn{1}{c}{ Aroma } \\
\hline 4 & Sangat beraroma asam \\
3 & Beraroma asam \\
2 & Agak beraroma asam \\
1 & Tidak beraroma asam \\
\hline
\end{tabular}

Skala penilaian dari tabel 1 - 4 (Nurhayati, 2006).

\section{HASIL DAN PEMBAHASAN}

Uji Organoleptik dilakukan oleh 10 panelis untuk menilai nata de Arenga yang disediakan. Panelis diminta untuk menilai nata de Arega pada aspek warna, rasa, tekstur dan aroma dengan menggunkan skala sesuai kuesioner panda lampiran 1. Pada hasil uji organoleptik dapat dilihat perbedaan antara masing-masing perlakuan Berdasarkan nilai rata-ratanya. Selain itu juga dapat mengetahui pengaruh 
suhu dan lama fermentasi terhadap uji organoletik nata de Arenga yang dihasilkan.

\section{Warna}

Hasil uji organoleptik terhadap warna nata de Arenga pinnata pada perlakuan suhu dan lama fermentasi dapat dilihat pada tabel 6 dibawah ini:

\section{Tabel 6. Hasil Uji Organoleptik Terhadap Warna Nata de Arenga pinnata.}

\begin{tabular}{rr}
\hline Perlakuan & Nilai \\
\hline C1A1 & 25 \\
C1A2 & 28 \\
C2A1 & 36 \\
C2A2 & 38
\end{tabular}

Keterangan: $\mathrm{C} 1 \mathrm{~A} 1=$ Suhu $28^{\circ} \mathrm{C}$ dan lama fermentasi 10 hari. $\mathrm{C} 1 \mathrm{~A} 2=\mathrm{Suhu} 28^{\circ} \mathrm{C}$ dan lama fermentasi 14 hari. $\mathrm{C} 2 \mathrm{~A} 1=$ Suhu $31^{\circ} \mathrm{C}$ dan lama fermentasi 10 hari. $\mathrm{C} 2 \mathrm{~A} 2=\mathrm{Suhu} 31^{\circ} \mathrm{C}$ dan lama fermentasi 14 hari.

Berdasarkan tabel 6 hasil penilaian panelis menunjukan nata de Arenga yang diperoleh dari 4 perlakuan memberikan nilai yang berbeda-beda. Hasil nilai rata-rata penilaian dari 10 panelis dengan menggunakan metode hedonik melalui pengujian organoleptik, panelis memberikan nilai skor terhadap warna nata de Arenga yaitu 2,5-3,8 ( tidak putih-sangat putih).

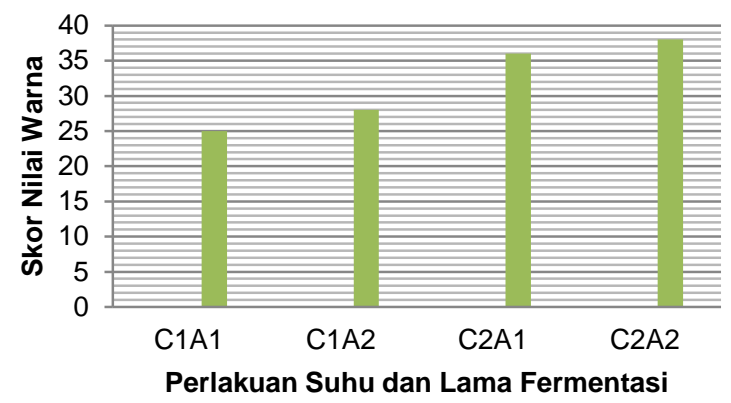

\section{Gambar 1. Hasil Uji Organoleptik Terhadap Warana Nata de Arenga pinnata.}

Dapat dilihat pada gambar 1 hasil uji organoleptik terhadap warna menunjukan warna nata de Arenga yang sangat putih oleh panelis adalah nata de arenga pada perlakuan C2A2 (suhu $31^{\circ} \mathrm{C}$ dan lama fermentasi 14 hari) memiliki skor 3,8 (sangat putih), sedangkan yang tidak putih oleh panelis adalah warna nata de Arenga pada perlakuan $\mathrm{C} 1 \mathrm{~A} 1$ (suhu $28^{\circ} \mathrm{C}$ dan lama fermentasi 10 hari) memiliki skor 2,5 (tidak putih) dan perlakuan $\mathrm{C} 1 \mathrm{~A} 2$ (suhu $28^{\circ} \mathrm{C}$ dan lama fermentasi 14 hari) dengan skor 2,8 (agak putih), sedangkan pada perlakuan C2A1 (suhu $30^{\circ} \mathrm{C}$ dan lama fermentasi 10 hari) memiliki skor 3,6 (agak putih).

\section{Rasa}

Hasil uji organoleptik terhadap rasa nata de Arenga pinnata pada perlakuan suhu dan lama fermentasi dapat dilihat pada tabel 7 dibawah ini:

Tabel 7. Hasil uji organolepti terhadap rasa nata de Arenga pinnata

\begin{tabular}{cc}
\hline $\begin{array}{l}\text { Perlakuan } \\
\text { rasa }\end{array}$ & Nilai organoleptik \\
\hline C1A1 & 33 \\
C1A2 & 33 \\
C2A1 & 33 \\
C2A2 & 33
\end{tabular}

Berdasarkan tabel 7 hasil penilaian panelis menunjukan nilai yang sama terhadap rasa nata de Arenga yang diperoleh dari 4 perlakuan. Hasil nilai ratarata penilaian dari 10 panelis dengan menggunakan metode hedonik melalui pengujian organoleptik, panelis memberikan nilai skor terhadap rasa nata de Arenga yaitu 3,3 (sangat tawar) pada semua perlakuan.

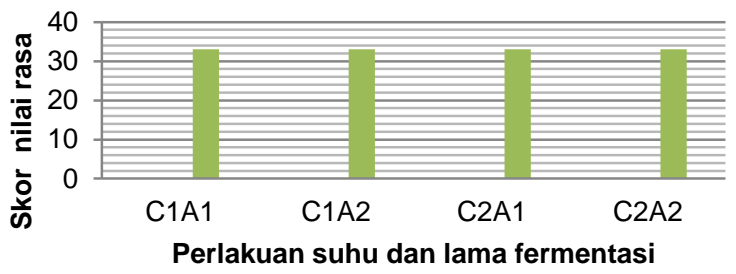

\section{Gambar 2. Hasil Uji Organoleptik Terhadap Rasa Nata de Arenga pinnata.}

Dapat dilihat pada gambar 2 hasil uji organoleptik terhadap rasa menunjukan rasa nata de Arenga yang sangat tawar oleh 10 panelis adalah nata de Arenga 
pada perlakuan $\mathrm{C} 1 \mathrm{~A} 1$ (suhu $2^{\circ} \mathrm{C}$ dan lama fermentasi 10 hari) memiliki skor nilai rasa 3,3 (sangat tawar), sama denga perlakuan $\mathrm{C} 1 \mathrm{~A} 2$ (suhu $28^{\circ} \mathrm{C}$ dan lama fermentasi 14 hari), perlakuan C2A1(suhu $31^{\circ} \mathrm{C}$ dan lama fermentasi 10 hari) dan perlakuan $\mathrm{C} 2 \mathrm{~A} 2$ (suhu $31^{\circ} \mathrm{C}$ dan lama fermentasi 14 hari) memiliki skor nilai rasa yang sama yaitu 3,3 (sangat tawar).

\section{Tekstur}

Hasil uji organoleptik terhadap tekstur nata de Arenga pinnata pada perlakuan suhu dan lama fermentasi dapat dilihat pada tabel 8 di bawah ini.

Tabel 8. Hasil Uji Organoleptik Terhadap Tekstur Nata de Arenga pinnata.

\begin{tabular}{rc}
\hline Perlakuan & Nilai Organoleptic Tekstur \\
\hline C1A1 & 16 \\
C1A2 & 24 \\
C2A1 & 24 \\
C2A2 & 33 \\
\hline
\end{tabular}

Berdasarkan tabel 8 hasil penilaian panelis menunjukan nilai yang berbedabeda terhadap tekstur nata de Arenga yang diperoleh dari 4 perlakuan. Hasil nilai ratarata penilaian dari 10 panelis dengan menggunakan metode hedonik melalui pengujian organoleptik, panelis memberikan nilai skor terhadap tekstur nata de arenga yaitu 1,6-3,3 (tidak kenyalsangat kenyal).

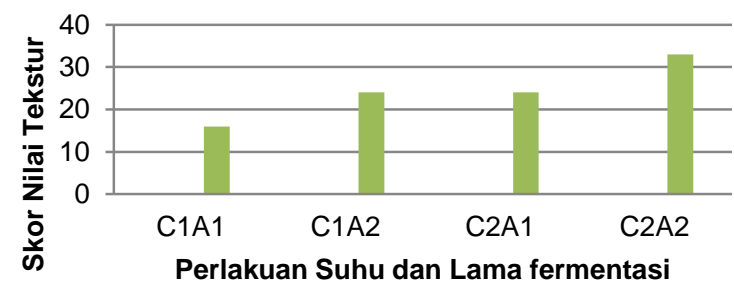

\section{Gambar 3. Hasil Uji Organoleptik Terhadap Tekstur Nata de Arenga pinnata.}

Dapat dilihat pada gambar 3 . hasil uji organoleptik terhadap tekstur menunjukan tekstur yang kenyal oleh panelis adalah nata de Arenga pada perlakuan C2A2 (suhu $31^{\circ} \mathrm{C}$ dan lama fermentasi 14 hari) dengan skor 3,3 (kenyal), dan yang paling tidak kenyal oleh panelis adalah tekstur pada perlakuan C1A1 (suhu ${ }^{28^{\circ} \mathrm{C}}$ dan lama fermentasi 10 hari) memiliki skor 1,6(tidak kenyal), dan perlakuan $\mathrm{C} 1 \mathrm{~A} 2$ (suhu $28^{\circ} \mathrm{C}$ dan lama fermentasi 14 hari) memiliki skor 2,4 (agak kenyal) dan sama halnya panda perlakuan $\mathrm{C} 2 \mathrm{~A} 1$ (suhu $31^{\circ} \mathrm{C}$ dan lama fermentasi 10 hari) memiliki skor yang sama yaitu 2,4 (agak kenyal).

\section{Aroma}

Hasil uji organoleptik terhadap tekstur nata de Arenga pinnata pada perlakuan suhu dan lama fermentasi dapat dilihat pada tabel 9 di bawah ini.

Tabel 9. Hasil Uji Organoleptik Terhadap Aroma Nata de Arenga pinnata.

\begin{tabular}{cc}
\hline $\begin{array}{l}\text { Perlakuan } \\
\text { tekstur }\end{array}$ & Nilai organoleptik \\
\hline C1A1 & 10 \\
C1A2 & 10 \\
C2A1 & 10 \\
C2A2 & 10 \\
\hline
\end{tabular}

Berdasarkan tabel 9 hasil penilaian panelis menunjukan nilai yang sama terhadap aroma nata de Arenga yang diperoleh dari 4 perlakuan. Hasil nilai ratarata penilaian dari 10 panelis dengan menggunakan metode hedonik melalui pengujian organoleptik, panelis memberikan nilai skor terhadap aroma nata de Arenga yaitu 1,0 (tidak beraroma asam).

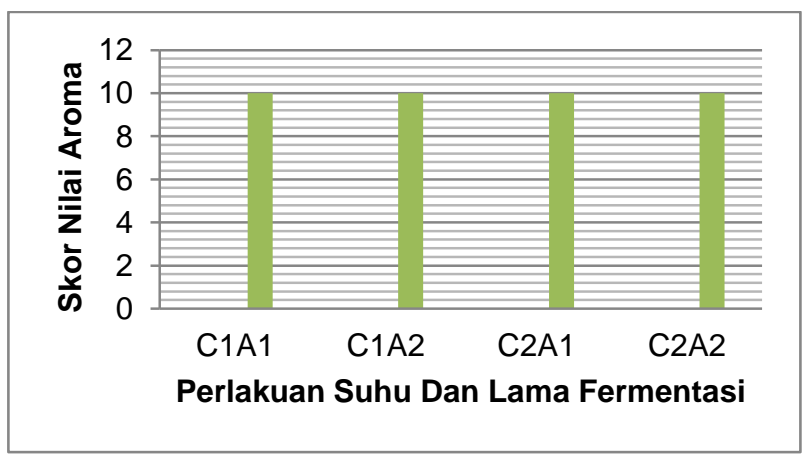

\section{Gambar 4. Hasil uji organoleptik terhadap tekstur nata de Arenga pinnata.}

Pada gambar 4 hasil uji organoleptik terhadap aroma menunjukan aroma nata de Arenga yang tidak harum oleh 10 panelis adalah nata de Arenga pada perlakuan 
C1A1(suhu $28^{\circ} \mathrm{C}$ dan lama fermentasi 10 hari) memiliki nilai 1,0 ( tidak beraroma asam), sama dengan perlakuan C1A2 (suhu $28^{\circ} \mathrm{C}$ dan lama fermentasi 14 hari), perlakuan $\mathrm{C} 2 \mathrm{~A} 1$ (suhu $31^{\circ} \mathrm{C}$ dan lama fermentasi 10 hari), dan perlakuan C2A2(suhu $31^{\circ} \mathrm{C}$ dan lama fermentasi 14 hari) memilki nilai skor yang sama terhadap aroma nata de Arenga pinnata yaitu 1,0 (tidak beraroma asam).

Berdasarkan hasil uji organoleptik, terlihat bahwa adanya perbedaan antara masing-masing perlakuan nata de Arenga pada beberapa aspek yaitu warna, dan tekstur sedangkan pada aspek rasa dan aroma tidak terdapat perbedaan. Dengan demikian terlihat adanya pengaruh suhu dan lama fermentasi terhadap uji organoleptik nata de Arenga. Menurut Pambayun (2002), suhu yang dibutuhkan dalam pembuatan nata adalah suhu kamar (28-31ํㅡ) dan suhu yang digunakan dalam penilitian ini adalah $28^{\circ} \mathrm{C}$ dan $31^{\circ} \mathrm{C}$. Sedangkan menurut Susanti (2006), lama fermentasi dalam pembuatan nata de Arenga adalah $8,10,12$, dan 14 hari dan lama fermentasi yang dilakukan dalam penilitian ini adalah 10 dan 14 hari.

Pada tabel 1 menunjukan bahwa adanya perbedaan pada masing-masing suhu dan lama fermentasi nata de Arenga. Secara deskriptif nata de Arenga yang memiliki nilai rata-rata tertinggi pada warna adalah perlakuan C2A2 yang memiliki nilai rata-rata 3,8 ; diikuti dengan perlakuan C2A1 memiliki nilai rata-rata 3,6; kemudian perlakuan C1A2 memiliki nilai rata-rata 2,8; sedangkan nilai rata-rata yang terendah adalah perlakuan C1A1 memiliki nilai ratarata 2,5. Warna putih kecoklatan terdapat pada perlakuan C1A1 yang memiliki nilai yang lebih rendah dikarena warna yang tampak pada nata buah enau berbeda satu sama lain, pada masing-masing suhu dan lama fermentasi. Kualitas pada warna nata dipengaruhi oleh nutrisi yang diberikan. Nata yang diberikan penambahan ekstrak tauge memiliki warna bening. Hal ini disebabkan semakin tinggi kadar nitrogen yang ditambahkan, maka nata akan semakin putih kecoklatan karena ion hidroksil nitrogen bereaksi dengan gula atau komponen yang lain pada bahan dasar dan salah satu hasilnya memiliki olah atau selama penyimpanan yang terjadi pada bahan pangan. pembentukan warna coklat tersebut dapat dipicu oleh aktivitas enzim atau gula yang mempunyai sifat yang dapat menyebabkan reaksi pencoklatan yaitu karamelisasi (Winarno, 2004).

Pada perlakuan C2A2 memiliki nilai yang tertinggi dan warna yang lebih putih dibandingkan perlakuan lainnya. Karna selain jenis nutrisi, warna pada nata buah enau juga dipengaruhi oleh lama fermentasi karena semakin lama fermentasi maka semakin banyak jalinan fibriler yang terbentuk sehingga menyebabkan warna nata menjadi pekat. Hal ini terbukti pada lama fermentasi 14 hari yang memiliki warna nata yang lebih pekat dibandingkan dengan lama fermentasi sebelumnya. Karena semakin lama fermentasi maka semakin banyak jalinan selulosa yang terbentuk akan menyebabkan nata buah enau yang dihasilkan pun semakin pekat yakni memiliki warna nata kecoklatan yang rendah (Loekmonohadi, 2002). Sehingga nata yang di hasilkan pada perlakuan suhu $31^{\circ} \mathrm{C}$ dan lama fermentasi 14 hari berwarn putih, pada proses pembuatan nata suhu juga merupakan salah satu factor yang mempengaruhi sifat nata. Menurut Pambayun (2002) suhu yang di butuhkan dalam pembuatan nata adalah suhu kamar $\left(28-31^{\circ} \mathrm{C}\right)$. Suhu yang terlalu tinggi maupun terlalu rendah akan menghasilkan nata yang kurang berkualitas atau aktivitas Acetobacter xylium terhambat.

Pada tabel 2 menunjukan adanya persamaan yang nyata pada masingmasing suhu dan lama fermentasi nata buah enau. Pada parameter rasa, pengukuran kualitasnya secara deskritif yakni dengan uji deskritif oleh 10 panelis. Secara deskriptif nata buah enau memiliki nilai rata-rata yang sama pada parameter rasa adalah rasa tawar pada semua perlakuan dengan nila rata-rata yakni 3,3. Rasa nata disebabkan oleh adanya komponen serat yang terdapat didalamnya. Struktur fibriler dan serat yang merupakan jalinan nata akan menyerap air dan menyebabkan struktur nata menjadi agaragar (Hariyatni, 2002). Substrat dari daging buah enau mempunyai nutrisi yang sesuai untuk pertumbuhan Acetobacter xylinum. Kondisi yang kemudian memungkinkan penggunaan media fermentasi secara optimal. Dengan demikian, nata yang 
dihasilkan tidak menimbulkan rasa asam dari asam cuka pada media fermentasi, sebab acetobacter xylinum secara optimal mampu membentuk selulosa ekstraseluler.

Berdasarkan hasil deskriptif rasa pada nata tidak ada pengaruh suhu dan lama fermentasi yang nyata terhadap rasa nata tersebut. Semakin lama waktu fermentasi maka semakin banyak kandungan air pada media yang mengisi rongga-rongga antar selulosa mengakibatkan nilai rasa semakin menurun (Setiawan, 2006). Hal ini diperkuat oleh Widya (1984), yang menyatakan bahwa rasa disebabkan oleh kekurangan unsur nitrogen yang mempengaruhi terbentuknya ikatan antara unsur nitrogen dengan prekursor polisakarida yang mempunyai struktur polimer yang menyatuh dan dapat meningkatkan jumlah serat yang menentukan rasa nata yang di hasilkan. Faktor lama fermentasi dan jenis nutrisi sangat berpengaruh terhadap rasa nata buah enau karena semakin fermentasi, maka semakin banyak kandungan air pada media yang mengisi rongga-rongga antar selulosa mengakibatkan rasa yang kurang baik. Rasa tawar juga dipengaruhi oleh rasa asli dari buah enau yang memiliki rasa tawar. Pada tabel 3 menunjukan adanya perbedaan pada masing-masing suhu dengan lama fermentasi nata de Arenga. Secara deskriptif nata de Arenga yang memiliki nilai rata-rata tertinggi pada tekstur adalah perlakuan C2A2 memiliki nilai ratarata 3,3: diikuti dengan perlakuan $\mathrm{C} 1 \mathrm{~A} 1$ dan C2A1 yang memiliki nilai rata-rata yang sama yakni 2,4; sedangkan nilai rata-rata yang terendah adalah produk dengan perlakuan C1A1 memiliki nilai rata-rata 1,6.

Perlakuan dengan suhu $31^{\circ} \mathrm{C}$ dengan lama fermentasi 14 hari memiliki tekstur lebih kenyal di bandingkan dengan tiga perlakuan lainnya. Hal tersebut dikarenakan pada perlakuan dengan suhu $31^{\circ} \mathrm{C}$ dengan lama fermentasi 14 hari hasil natanya agak lebih tebal sehingga tekstur yang dirasakan oleh para panelis adalah kenyal. Suhu $31^{\circ} \mathrm{C}$ merupakan suhu yang dibutuhkan dalam pembuatan nata. Suhu yang terlalu tinggi atau terlalu rendah akan menghasilkan nata yang kurang baik atau aktifitas Acetobacter xylinum terhambat (Pambayun, 2002). Selanjutnya dalam proses fermentasi 14 hari merupakan fase pertumbuhan, pada fase ini jumlah sel yang tumbuh relatif sama dengan jumlah sel yang mati. Penyebab adalah didalam media terjadi kekurangan nutrisi, pengaruh metabolit toksit lebih besar dari umur sel semakin tua. Namun panda fase ini sel akan lebih tahan terhadap kondisi lingkungan yang ekstrik jika dibandingkan dengan ketahanan panda fase yang lain. Matrik nata lebih baik diproduksi panda fase ini. Sedangkan paada perubahan suhu $28^{\circ} \mathrm{C}$ dengan lama fermentasi 10 hari menghasilkan nata yang tidak kenyal. Suhu $28^{\circ} \mathrm{C}$ juga merupakan suhu yang dibutuhkan dalam pembuatan nata. Suhu yang terlalu rendah atau terlalu tinggi akan mengganggu pertumbuhan bakteri pembentuk nata, yang akhirnya juga menghambat produksi nata (Budiyanto, 2004).

Selanjutnya pada lama fermentasi 10 hari disebut juga fase pertumbuhan logaritmik yang ditandai dengan pertumbuhan yang sangat cepat. Untuk bakteri Acetobacter xylinum pada fase ini dicapai dalam waktu antara 1-5 hari tergantung pada kondisi lingkungan. Baktri Acetobacter xylinum dalam membentuk nata. Tapi pada perlakuan ini nata yang dihasilkan tidak kenyal dikarenakan natanya sangat tipis sehingga kekenyalannya tidak dirasakan oleh para panelis. Pada semua perlakuan nata buah enau ketebalan yang dihasilkan kurang baik dikarenakan ketebalan yang dihasilkan tergantung dari lamanya fermentasi. Semakin lama fermentasi, nata yang terbentuk akan semakin tebal.

Faktor lain yang berpengaruh terhadap ketebalan adalah ketinggian medium dalam wadah, apabila volume cairan medium yang ditambahkan jumlahnya sama tetapi jenis wadah yang digunakan mempunyai ketinggian dan luas permukaan yang berbeda, maka wadah yang permukaannya luas dan lebih dangkal akan lebih cepat memperoleh ketebalan yang sama begitu juga sebaliknya dan jumlah bakteri yang digunakan dalam medium harus dapat disesuaikan banyaknya. Pada tabel 4 menunjukan adanya persamaan terhadap nilai parameter aroma yang diberikan oleh 10 panelis. Pada parameter aroma, pengukuran kualitas hanya secara deskriptif yakni uji deskriptif oleh 10 panelis yang memberikan penilaian rata-rata sama yakni 1,0 (tidak beraroma asam) pada semua 
perlakuan. Hasil tersebut disebabkan sampel nata yang diberikan telah melalui proses perendaman, pencucian, perebusan yang belum diberi penambahan pemanis dan penyedap rasa. Untuk perlakuan C1A1 mendapatkan nilai skor yang tidak berbeda dengan 3 perlakuan laiannya yaitu perlakuan $\mathrm{C} 1 \mathrm{~A} 2, \mathrm{C} 2 \mathrm{~A} 1$ dan C2A2. Hal ini disebabkan karena pada perlakuan C1A1 aromanya tidak beraaroma asam dan hasilnya sama dengan perlakuan laiannya yaitu C1A1, C1A2, C2A1 dan C2A2, hasil tersebut disebabkan karrna nata yang diberikan telah melalui proses pencucian, perendaman, perebusan yang belum diberi penambahan pemanis dan penyedap rasa layaknya nata yang siap dikonsumsi dan beredar di pasaran. Hal ini sesuai dengan pernyataan Saragih (2004), bahwa setelah pemanenan nata perlu segera dilakukan perendaman dengan air tawar dan sering diganti hingga aroma asam pada nata hilang dan setelah itu dilakukan perebusan hingga mendidih. Setelah dua proses tersebut nata tawar siap dikemas dalam hangat dan siap dipasarkan serta dikonsumsi, untuk produk nata manis bisa ditambahkan sirup dan gula saat perebusan.

Hasil organoleptik terhadap warna, rasa, tekstur dan aroma saling berkaitan antara satu dan lain pada kualitas nata. Pada pembuatan nata dengan menggunakan buah enau (Arenga pinnata Merr) merupakan bahan yang cukup baik untuk digunakan dalam pembuatan nata de Arenga pinnata. Hasil organoleptik menunjukan bahwa panelis lebih menyukai perlakuan dengan menggunakan suhu $31^{\circ} \mathrm{C}$ dan lama fermentasi 14 hari (C2A2) karena pada proses fermentasi dilakukan pengendalian mutu dengan mengatur suhu penyimpanan fermentasi dalam suhu $31^{\circ} \mathrm{C}$ karena suhu dan kelembapan mempengaruhi faktor keberhasilan fermentasi. Suhu optimum bagi pertumbuhan bakteri $A$. xylinum menurut Pambayun (2002), adalah $28^{\circ} \mathrm{C}-31^{\circ} \mathrm{C}$, dan dengan lama fermentasi maka semakin banyak jalinan selulosa yang terbentuk akan menyebabkan nata buah enau yang dihasilkan pun semakin pekat yakni memiliki warna nata kecoklatan yang rendah (Loekmonohadi, 2002), sehingga nata yang dihasilkan berwarna putih dan tekstur yang kenyal sedangkan pada organoleptik rasa memiliki rasa tawar disebabkan karna oleh kekurangan unsur nitrogen yang mempengaruhi terbentunya ikatan antara unsur nitrogen dengan prekursor polisakarida yang mempunyai struktur polimer yang menyatuh dan dapat meningkatkan jumlah serat yang menentukan rasa nata yang dihasilkan dan aroma nata tidak beraroma asam disebabkan karna setelah pemanenan nata perlu segera dilakukan perendaman dengan air tawar sering diganti dan di rebus setelah itu nata tawar siap dikemas dalam hangat dan siap dipasarkan serta dikonsumsi, untuk produk nata yang manis bisa ditambahkan sirup dan gula saat perebusan (Saragih 2004).

\section{KESIMPULAN}

Dari hasil penilitian pengaruh suhu dengan lama fermentasi terhadap nilai uji organoleptik pada pembuatan nata buah enau dapat di simpulkan bahwa : Adanya pengaruh suhu dengan lama fermentasi terhadap nilai uji organoleptik pada pembuatan nata buah enau yaitu pada warna dan tekstur nata buah enau. Sedangkan pada rasa dan aroma tidak terdapat pengaruh suhu dan lama fermentasi terhadap nilai uji organoleptik pada pembuatan nata buah enau.

\section{DAFTAR PUSTAKA}

Budiyanto, Agus Krisno. 2002. Mikrobiologi Terapan. Penerbit Universitas Muhammadiyah Malang.

Hariyatni, T. 2002 Mempelajari Pengaruh Komposisi Bahan Terhadap Mutu Fisik dan Stabilitas Warna Nata de Coco. Bogor: IPB.

Loekmonohadi. 2002. Kimia Makanan. Semarang. Fakultas Teknik UNNES. Semarang.

Muhidin. 2001. Peningkatan Kandungan Protein Kulit Umbi Kayu Proses Fermentasi . JMS

Nadiyah. 2005. Kemampuan Bakteri Acetobacter Xylinum Mengubah Karbohidrat Pada Limbah Padi Menjadi Selulosa. Biosciential, Vol 2, No. 2. Hal: 37-47. http://biosciential.tripod.com. 
Nurhayati, Ai. 2006. Penilian Inderawi (Uji Organoleptik). Handout. Bandung: Fakultas Pendidikan Teknologi dan Kejuruan, Jurusan Pendidikan Kesejateraan Keluarga, Universitas Pendidikan Indonesia.

Sumarni, G., Ismanto, A., dan Muslich, M., 2003. Keawetan Batang Aren (Arenga pinnata Merr). Buletin, Penilitian Hasil Hutan. Vol 21 No.2 Hal. 167-173.

Saragih. 2004. Membuat Nata de coco. Jakarta: Puspa Swara

Sumiyatni. 2009. Kualitas nata de Cassava Limbah Cair Tapioka Dengan Penambahan Gula Pasir dan Lama Fermentasi yang Berbeda. (skripsi). Surakarta Universitas Muhammadiyah Surakarta.

Susanti, L. 2006. Perbedaan Penggunaan Jenis Kulit Pisang Terhadap Kualitas Nata. (skripsi). Semarang. Universitas Negeri Semarang.

Setyawan, O. 2006. Pengaruh Jumlah Acetobacter Xylinum dan Konsentrasl Ammonium Sulfat Terhadap Produksi Natta de Pina. Skripsi. Fakultas Pertanian Universitas Riau.

Pramesti, Novita. 2007. Faktor Pertumbuhan Nata. Dari http://novitapramesti.com

Blogspot.com/2007/05/ Faktorpertumbuhan- nata. Diakses tanggal 13 juni 2015.

Pambayun R. 2002. Teknologi Pengolahan Nata de Coco. Yogyakarta Kanisius.

Winarno, F. G. 2004. Kimia Pangan dan Gizi. PT. Jakarta : Gramedia Pustaka Utama.

Widya, I. W. 1984 Mempelajari Pengaruh Penambahan Skin Milk Kelapa, Jenis Gula, dan Mineral Dengan Berbagai Konsentrasi Pada Pembuatan Natta de Coco. Skripsi (Tidak Di Publikasikan) Bogor: IPB. 